\title{
UK government lobbying for increased spending on universities intensifies
}

The last two months have seen growing pressure on the British government to increase university funding to ensure that the standard of scientific research in the UK is not damaged irreparably.

Pharmaceutical manufacturers with a base in the UK, the House of Commons Science and Technology Committee and the Office of Science and Technology (OST) have all stressed the need for the government to increase support for basic university facilities. Some parties estimate that $£ 500$ million ( $\$ 840$ million) is needed over the next three years to end the crisis.

On March $30^{\text {th }}$, pharmaceutical companies including Glaxo Wellcome (GW), SmithKline Beecham and

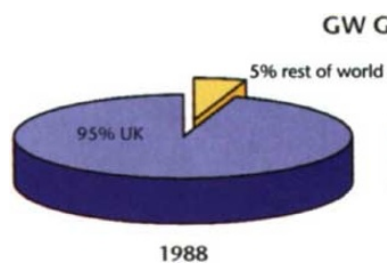

GW Grants
Skingle says that dealings with UK universities "are better now than they ever were," the availability of high-tech telecommunications systems means that industry is no longer forced to use collaborators within close geographical proximity. "Research is a global activity and we're going to go where we can get quality research done in a timely fashion," Skingle told Nature Medicine.

Concerns that UK industries may find foreign universities more appealing were

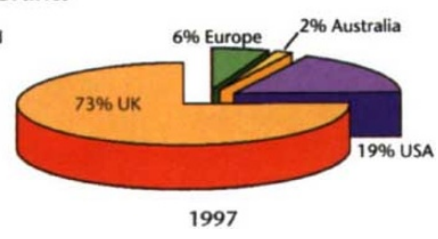

although the Commons agreed that there is a "real and urgent need for additional resources to resolve the immediate crisis in research infrastructure" it concluded that a revolving loan fund is "implausible."

Meanwhile, Skingle says that industry is happy to support ventures such as the Joint Research Equipment Initiative (JREI) provided that the equipment in question is state-of-the-art. Under the JREI, research equipment is purchased using funds donated on a 50:50 basis by the government and industry. But the problem, warns Skingle, is that "industry is not prepared to pay for bread and butter equipment, particularly when equipment we are being asked to contribute towards is below

echoed in a House of Commons Science and Technology Committee document released on April $2^{\text {nd }}$. The Commons stated that "under-investment in laboratories and research equipment is undermining researchers' ability to attract private sector research funding to conduct research at the cutting edge." In fact, there has been a 35 percent drop in government funding of higher education in the UK in the last decade. The poor state of university infrastructure was highlighted last year in the Dearing Report and by charities such as the Wellcome Trust (Nature Med., 3; 1185, 1997).

Because industry typically wants to retain control over where and how its research money is spent, Skingle believes that paradigms such as the revolving loan scheme proposed in the Dearing Report-according to which the government and industry would establish a fund of $£, 400-500$ million to support infrastructure in a limited number of university research departments that can bid for the money-are not plausible. The government is also believed to be in favor of case-by-case funding rather than a central pot of money.

Aspects of the Dearing Report were criticized in the Commons document, which charged that it "almost completely ignored the important areas of multi-disciplinary and collaboration research." And our own internal specifications."

Finally, in a report prepared for the OST by each of the seven government Research Councils, in which they identify the strengths, weaknesses opportunities and threats (SWOT) of their area of scientific interest, under-investment in laboratory equipment along with a decrease in the number of students pursuing scientific careers are recognized as the greatest threats to the UK's science base (Research Fortnight, $8^{\text {th }}$ April 1998).

The SWOT analysis by the Medical Research Council (MRC)--which is responsible for the distribution of biomedical research funding-highlights the current failure to develop expertise in bioinformatics within the country. If not corrected, this deficit will seriously undermine future competition in fields such as genetics and molecular biology, reports the MRC. In light of the public health threat posed by re-emerging infectious diseases, the MRC also calls for the establishment of a sound ethical framework to support the use of databases for health research at the population level. Another area of weakness identified is the poor integration of clinical and basic medical research and the social sciences.

The Research Councils are estimated to operate on a combined budget of $£ 1$ billion. The SWOT reports will be submitted as part of OST's document to the government for its Comprehensive Spending Review which is due to take place this summer.

Karen Birmingham, NeW York 